\title{
Size of spleen rather than amount of platelet sequestration may determine long term responses to splenectomy in adult idiopathic thrombocytopenic
} purpura

\author{
BJ BOUGHTON, ${ }^{*}$ P SMITH, ${ }^{*}$ J FIELDING, $\dagger$ R HAWKER, $\dagger$ I WILSON, $\uparrow S$ CHANDLER, $\ddagger$ \\ A HOWIE§
}

From the Departments of *Haematology, †Surgery, ¥Nuclear Medicine, and §Pathology, Queen Elizabeth Hospital, Edgbaston, Birmingham

SUMMARY Fourteen adults with idiopathic thrombocytopenic purpura suffered a relapse after treatment with steroids, vinca alkaloids, or intravenous gammaglobulin. Splenic sequestration of platelets labelled with ${ }^{111}$ In-oxine was assessed, and the patients then underwent splenectomy. During follow up of four to 47 months (mean 20.7) none of the patients required further treatment, including three of 14 who showed partial relapses. Splenic sequestration patterns did not predict relapses, but an unexpected finding was that patients who relapsed had significantly smaller spleens. It is concluded that splenectomy is beneficial in most adult patients with idiopathic thrombocytopenic purpura and that radiological techniques to measure the size of the spleen may be useful in predicting which patients may relapse.

Idiopathic thrombocytopenic purpura in adults responds to treatment with corticosteroids in 25$44 \%$ of patients. ${ }^{2}$ Splenectomy is usually indicated in patients who fail to respond or who relapse when steroids are reduced as destruction of platelets occurs mainly in the spleen, and $80-90 \%$ of patients achieve complete remission after splenectomy. ${ }^{2}$ Attempts have been made to predict the small number of patients who respond incompletely to splenectomy, using platelets labelled with radioisotopes to determine the pattern of destruction of platelets in the liver, spleen, and bone marrow. Although splenic or hepatic sequestration patterns, or a combination of both, denote a good chance of complete remission after splenectomy, ${ }^{3-5}$ these patterns can be misleading, and many haematologists would advise splenectomy regardless of the sequestration patterns. ${ }^{1}$

Unlike ${ }^{51} \mathrm{Cr}$ and other conventional isotope labels for platelets, "In-oxine is a high energy gamma emitter that gives complete gamma camera images of organs that pool or sequester cells. ${ }^{6-8}$ This study was undertaken to assess the usefulness of this promising technique.

Accepted for publication 21 May 1985

\section{Material and methods}

PATIENTS

Idiopathic thrombocytopenic purpura was diagnosed in 14 patients using conventional criteria. ${ }^{1}$

LABELLING OF PLATELETS WITH '"In

In 12 patients with platelet counts $>20 \times 10^{9} / 1$ autologous cells were labelled as previously described. ${ }^{9}$ ABO compatible heterologous platelets were used in two patients in whom the platelet count was $<20$ $\times 10^{9} / 1$ at the time of the study. The total activity injected was $2.8 \mathrm{MBq}(75 \mu \mathrm{Ci})$.

\section{IMAGING OF THE ORGAN}

Images were obtained with a LFOV gamma camera (Searle) linked to a DEC PDP-11 computer, and platelet sequestration was estimated from anterior and posterior views at 20 minutes and one, four, and 24 hours after intravenous injection of labelled platelets.

\section{STATISTICS}

Statistical differences were assessed using Wilcoxon's rank sum tests, and correlation was measured by the method of least squares fit. 


\section{Results}

The Table shows details of 14 patients who had not achieved complete remissions with steroids, vincristine, or sandoglobulin. All showed a recovery of normal platelet counts after splenectomy; in 11 patients this remission was maintained for four to 47 months without recourse to additional treatment. In three patients followed up for 12 to 23 months, however, the platelet counts fell to 60,96 , and 104 $\times 10^{9} / 1$, respectively. In all three patients, however, the relapsed counts were at least double the preoperative values, and these patients also did not require additional treatment.

In the 11 patients who remained in postoperative remission the 24 hour splenic sequestration of ${ }^{11}$ In labelled platelets was 28-97\% of the total injected cells. The corresponding values in the three patients who relapsed was $10-47 \%$, and this was not significantly different $(p>0 \cdot 1)$.

The Figure shows, however, that the weight of spleens removed at operation was significantly smaller in patients who relapsed $(p<0 \cdot 01)$. The weight of the spleen did not correlate significantly with the patient's age, the duration of disease, or previous treatment. Furthermore, the early splenic pooling of platelets at 20 minutes might be expected to correlate with the splenic weight, but this was not the case.

The histopathological appearances of the spleens showed prominent germinal centres in five patients whose postoperative remissions were maintained, but these appearances were unrelated to the weight

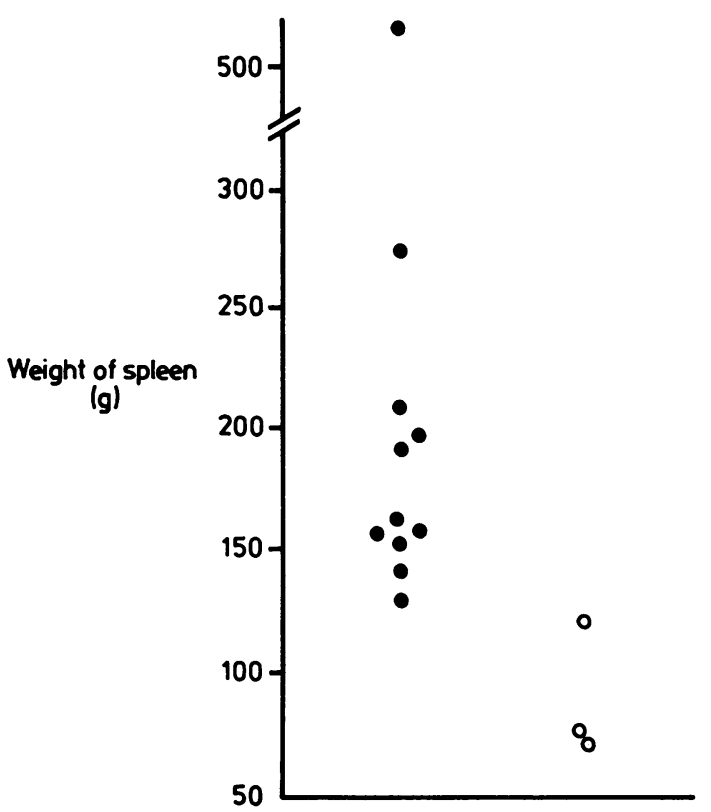

Weight of spleen $(\mathrm{g})$ in 14 patients who underwent splenectomy. Three patients who relapsed $(O)$ had significantly smaller spleens than 11 whose remission was maintained (๑).

of the spleen. The histological appearances were normal in the six other patients in this group and in all three patients who relapsed.

Haematological details of 14 patients with idiopathic thrombocytopenic purpura

\begin{tabular}{|c|c|c|c|c|c|c|c|c|}
\hline \multirow[t]{2}{*}{ Age and sex } & \multirow{2}{*}{$\begin{array}{l}\text { Preoperative } \\
\text { duration of } \\
\text { idiopathic } \\
\text { thrombocytopenic } \\
\text { purpura (months) }\end{array}$} & \multirow{2}{*}{$\begin{array}{l}\text { Unsuccessful } \\
\text { previous } \\
\text { treatment }\end{array}$} & \multicolumn{3}{|c|}{ Platelet count $\left(\times 10^{9} / l\right)$} & \multirow{2}{*}{$\begin{array}{l}\text { Postoperative } \\
\text { follow up } \\
\text { (months) }\end{array}$} & \multicolumn{2}{|c|}{ Splenic uptake (\%) } \\
\hline & & & Preoperatively & $\begin{array}{l}\text { Postoperatively } \\
\text { (maximum) }\end{array}$ & Recently & & 20 minutes & 24 hours \\
\hline \multicolumn{9}{|c|}{ Patients in complete remission } \\
\hline $19 \mathrm{M}$ & 6 & $\begin{array}{l}\text { Steroids } \\
\text { Vincristine } \\
\text { IgG }\end{array}$ & 83 & 452 & 250 & 8 & 50 & 97 \\
\hline $\begin{array}{l}28 \mathrm{~F} \\
20 \mathrm{M}\end{array}$ & $\begin{array}{l}96 \\
30\end{array}$ & $\begin{array}{l}\text { Steroids } \\
\text { Steroids } \\
\text { Vincristine }\end{array}$ & $\begin{array}{r}8 \\
13\end{array}$ & $\begin{array}{r}818 \\
1170\end{array}$ & $\begin{array}{l}312 \\
221\end{array}$ & $\begin{array}{l}28 \\
47\end{array}$ & 59 & $\begin{array}{l}86 \\
83\end{array}$ \\
\hline $17 \mathrm{M}$ & 60 & $\begin{array}{l}\text { Steroids } \\
\text { Vincristine }\end{array}$ & 12 & 381 & 248 & 30 & & 82 \\
\hline $\begin{array}{l}36 \mathrm{M} \\
27 \mathrm{~F} \\
30 \mathrm{~F} \\
17 \mathrm{M} \\
15 \mathrm{~F} \\
16 \mathrm{~F} \\
60 \mathrm{M}\end{array}$ & $\begin{array}{r}144 \\
24 \\
17 \\
120 \\
5 \\
48 \\
3\end{array}$ & $\begin{array}{l}\text { Steroids } \\
\text { Steroids } \\
\text { Steroids } \\
\text { Steroids } \\
\text { Steroids } \\
\text { Steroids } \\
\text { Steroids }\end{array}$ & $\begin{array}{r}37 \\
52 \\
34 \\
1 \\
60 \\
22 \\
14\end{array}$ & $\begin{array}{r}504 \\
376 \\
348 \\
1638 \\
810 \\
436 \\
708\end{array}$ & $\begin{array}{l}213 \\
281 \\
261 \\
301 \\
509 \\
200 \\
323\end{array}$ & $\begin{array}{r}10 \\
26 \\
4 \\
17 \\
24 \\
14 \\
25\end{array}$ & $\begin{array}{l}46 \\
37 \\
43 \\
27 \\
19 \\
25\end{array}$ & $\begin{array}{l}70 \\
70 \\
68 \\
36 \\
35 \\
34 \\
28\end{array}$ \\
\hline $\begin{array}{l}59 \mathrm{~F} \\
69 \mathrm{~F} \\
20 \mathrm{~F}\end{array}$ & $\begin{array}{r}12 \\
16 \\
7\end{array}$ & $\begin{array}{l}\text { Steroids } \\
\text { Steroids } \\
\text { Steroids }\end{array}$ & Patients & $\begin{array}{l}\text { ho relapsed } \\
360 \\
328 \\
335\end{array}$ & $\begin{array}{r}104 \\
96 \\
60\end{array}$ & $\begin{array}{l}23 \\
12 \\
23\end{array}$ & $\begin{array}{l}40 \\
15 \\
39\end{array}$ & $\begin{array}{l}43 \\
10 \\
47\end{array}$ \\
\hline
\end{tabular}




\section{Discussion}

Adult idiopathic thrombocytopenic purpura is usually associated with occasional spontaneous bleeding, but patients may nevertheless be advised to modify their lifestyle to avoid possible injury and to avoid drugs that impair platelet function, especially during episodes of viral illness. Some physicians are conscious of the increased risk of serious infection after splenectomy, ${ }^{10}$ and would advise splenectomy only in patients with repeated haemorrhagic problems. ${ }^{11}$ The risk of serious bleeding, particularly intracranial bleeding, remains, however, and it is common practice, therefore, to recommend splenectomy in all patients who are fit for surgery. ${ }^{1}$

This study shows that all 14 patients benefited from splenectomy during follow up of up to 47 months. The use of ${ }^{\prime \prime}$ In labelled platelets produces excellent gamma camera images of the organ and avoids some of the problems with collimator positioning encountered when ${ }^{51} \mathrm{Cr}$ is used as a label. ${ }^{12}$ As in previous studies, however, the technique did not identify the patients who subsequently relapsed. ${ }^{812}$ The lowest 24 hour splenic sequestration observed was $10 \%$, and even in this patient the postoperative platelet count was double the preoperative value. None of our patients needed additional treatment.

Our observation that a small spleen correlates with subsequent relapse has not been recorded previously. Splenic pooling 20 minutes after injection of radiolabelled platelets did not correlate with the weight of the spleen, but other techniques such as computed tomography should be able to distinguish these small spleens preoperatively.

Histological examination did not show any differences in the smaller spleens of patients who relapsed. All 14 patients developed normal platelet counts three weeks postoperatively, and the increased platelet counts were in excess of what would be expected after the removal of the splenic platelet pool.

All of our patients were improved by splenectomy, and this corresponds with the removal of the principal site of platelet destruction. The spleen, however, is also a principal site of production of platelet antibody, and the finding of increased germinal centres in five of the 11 patients with sustained remissions could indicate that these organs were the most important, if not the sole, site of pro- duction of antibody. Some of the patients without this feature were followed up for only short periods, and as the three relapses occurred after 10-17 months some of the patients currently in remission may possibly also relapse at a later date.

The cause of relapse is not clear from these observations, but the growth of accessory splenic tissue is an unlikely explanation in view of the careful search that was made for splenunculi at operation and the documented rarity of splenunculi reported. ${ }^{13} \mathrm{~A}$ more likely explanation, therefore, is increasing production of antibody in non-splenic sites, with sequestration of sensitised cells in the bone marrow and organs such as the liver.

\section{References}

' Karpatkin S. Autoimmune thrombocytopenic purpura. Blood 1980;56:329-43.

${ }^{2}$ McMillan R. Chronic idiopathic thrombocytopenic purpura. $N$ Engl J Med 1981;304:1135-47.

${ }^{3}$ Najean Y, Ardaillou N. The sequestration site of platelets in idiopathic thrombocytopenic purpura: its correlation with the results of splenectomy. Br J Haematol 1971;21:153-64.

${ }^{4}$ Ries CA, Price DC. ${ }^{51} \mathrm{Cr}$ platelet kinetics in thrombocytopenia. Correlation between splenic sequestration of platelets and response to splenectomy. Ann Intern Med 1974;80:702-7.

${ }^{s}$ Gugliotti L, Isacchi G, Guarni A, et al. Chronic idiopathic thrombocytopenic purpura (ITP). Site of platelet sequestra- $\triangle$ tion and results of splenectomy. Scand $J$ Haemato 1981;26:407-12.

${ }^{6}$ Baker JRJ, Butler KD, Eakins MN, Pay GF, White AM. Subcellular localization of "'In in human and rabbit platelets. Blood 1982;59:351-9.

${ }^{7}$ Heyns DP, Lotter MG, Badenhorst PN, et al. Kinetics, distribution and sites of destruction of "'indium labelled platelets. $\mathrm{Br} \mathrm{J}$ Haematol 1980;44:269-80.

${ }^{8}$ Siegel RS, Coleman RE, Kurlander R, Rosse WF. Platelet turnover; an important factor in predicting the response to splenectomy in autoimmune thrombocytopenic purpura. Blood 1984;64:241a

' Hawker RJ, Hawker LM, Wilkinson AR. Indium (111-In) labelled human platelets: optimal method. Clin Sci 1980;58:243-8.

${ }^{10}$ Walker W. Splenectomy in childhood: a review in England and Wales 1960-4. Br J Surg 1976;63:36-43.

${ }^{11}$ Crosby WH. Wet and dry purpura. JAMA 1975;232:744-5.

${ }^{12}$ Ries CA. Platelet kinetics in autoimmune thrombocytopenia: relation between splenic sequestration and response to splenectomy. Ann Intern Med 1977;86:194-5.

${ }^{13}$ Sweeney JD, Keane FB, Freyne PJ, Temperley IJ, McCann SR. Accessory splenic tissue in a patient with relapsed thrombocytopenic purpura. Clin Lab Haematol 1982;4:309-12.

Requests for reprints to: Dr BJ Boughton, Department of Haematology, The Queen Elizabeth Hospital, Queen Elizabeth Medical Centre, Edgbaston, Birmingham B15 2TH, England. 